\title{
COMPARATIVE ANALYSIS OF FILIPINO AND INDONESIAN MONOPHTHONGS
}

\author{
Cristian D. Arizo ${ }^{1}$, Alyssa L. Palayon ${ }^{2}$, Angela Paula V. Tornito ${ }^{3}$, Bayu Permana Sukma $^{4}$ \\ ${ }^{1}$ Department of English, Foreign Languages and Linguistics, \\ Polytechnic University of the Philippines \\ ${ }^{4}$ Badan Pengembangan dan Pembinaan Bahasa \\ Email: arizocris13@gmail.com
}

\begin{abstract}
Filipino and Indonesian belong to the Austronesian language family and this explains why they exhibit many linguistic similarities and numerous cognates. This study aims to further compare the two languages and establish their connection through phonology. The researchers use the cognates to compare the Filipino and Indonesian monophthong vowels. Qualitative method is utilized. The result shows that Filipino and Indonesian have a very similar vowel system with the exception of Indonesian having /a/ phoneme. It was also found out that most of the changes in monophthongs between the two languages appear in medial position. Moreover, most changes are from the mid back rounded vowel /o/ in Filipino to high back rounded vowel /u/ in Indonesian. Lastly, the changes in the unrounded vowels in Filipino usually appear in the initial and medial position whereas in the rounded vowels in Filipino, changes only appear in either the medial or final position.
\end{abstract}

Keywords: comparative analysis, Filipino, Indonesian, monophthongs

\section{INTRODUCTION}

The Philippines and Indonesia are the archipelagic countries situated in the vast region of Southeast Asia. Aside from being located in the same continent, these two are also part of the same area called Insular region along with Malaysia, Singapore, Brunei, East Timor (Danielson, 2009). With this, it is not surprising that the Philippines and Indonesian share the same feature of having volcanic and tropical archipelagos. However, their location is not the only thing that intertwines them. In fact, these two also possess linguistic connection (Lim, 2018).

With the existence of more than 7,107 islands in the Philippines, comes over 168 languages that are being spoken natively. The diversity of the Philippines in terms of culture and language makes it hard to recognize which language will be standardized as the national language. President Manuel L. Quezon, during 1935, added an article on Philippine Constitution to develop a national language based on the existing native languages in the Philippines. Two years later, the committee assigned Tagalog as the basis of the national language among the native languages, which was later called Pilipino. In our current 1987 constitution, it was stated that, "the National language of the Philippines is Filipino." 
Filipino language is the standardized variety of the Tagalog language. Tagalog language is widely used in the Philippines and, in fact, almost one-third of the population of the Philippines use it. Interestingly, the Tagalog language, along with the 160 native languages in the Philippines, is part of the Austronesian family of language. In addition, Blust (2018) named Cebuano, Tagalog, Ilocano, Hiligaynon, Bicol, Waray-Waray, Kapampangan and Pangasinan of the Philippines as parts of the major Austronesian languages.

On the other hand, the Philippines's neighboring country, Indonesia has 16,056 islands (Kusnandar, 2019) that contribute to the existence of 718 different native languages (Badan Pengembangan dan Pembinaan Bahasa, 2019) in the country. It is supported by the fact that over $80 \%$ of the Indonesian population speak indigenous local languages other than Indonesian (Whitehead, 2013), which means that even though it is understood and spoken by $90 \%$ of the Indonesian citizens, Indonesian is the second language of its most speakers (Wikipedia, 2020).

In 1928, the Indonesian nationalist movement chose Bahasa Indonesia as their national language. Bahasa Indonesia means the language of Indonesian. This language, mostly derived from Malay (Badan Pengembangan dan Pembinaan Bahasa, 2020b), is also part of the Austronesian family of language. Blust, (2018) stated that "the remaining 900 Austronesian languages are about equally divided among Indonesian (including the western half of the large island of New Guinea) and the Pacific islands of Melanesia, Micronesia and Polynesia."

The Filipino and Indonesian are part of one language family, the Austronesian. This results to some linguistic similarities that are present to both languages. For instances, there are words used in Indonesian that Filipino also use like mahal. In Indonesia, this means 'expensive' or 'high-priced' while in Filipino, the meaning of mahal can be expensive or love. There are also words in both languages that has the same meaning but there are minimal changes on the words such as changes in vowels and consonants. For example, in Filipino, ako which means ' $I$ ' is pronounced $a k u$ in Indonesian.

To further establish the connection of Filipino and Indonesian, this study will focus on the smallest unit of sound, phonemes, to further compare the two languages. It will specifically tackle the vowel monophthongs. By observing the phonological similarities of Filipino language and Indonesian, this study aims to answer these questions:

1. What are the similarities and differences in the monophthongs of similar Filipino words and Indonesian words?

2. How do the changes in monophthongs occur in Filipino and Indonesian?

Thus, this study will conduct a contrastive-phonological analysis, one of the branches of linguistics to do with the analysis of phonemes (and their orders) of two languages (Tarigan in Mulyaningsih, 2014).

\section{REVIEW OF LITERATURE}

\section{The Austronesian Migration Theory}

Bellwood (1984, p. 108) states that, "between about 4000 B.C. and A.D. 1000 the members of a major linguistic group of mankind, the Austronesians, underwent an expansion and dispersal for which there for which there is no parallel in human history. Their descendants now number perhaps 250 million people and occupy Indonesian, Malaysia, the Philippines, parts of southern Vietnam, Madagascar, and most of the Pacific Islands as far east as Easter Island". Bellwood (1984, p.108) also writes:

\section{"During the $5^{\text {th }}$ and $4^{\text {th }}$ millennia B.C. early Austronesians with a cereal-based}


economy (rice and millet) expanded from southern China to Taiwan and the northern Philippines. There, and later, throughout most of Indonesian, they had technological and demographic (high population density) advantages that allowed them to replace gradually the indigenous hunter-gatherer Australoid population".

This proposed theory also explains the similarities in the culture such as tattooing; Austronesian family of languages and; physical attribute from different countries in Asia.

However, Henry Otley Beyer, the father of Philippine Anthropology proposed the Wave Migration Theory which the ancestors of people of the Philippines travelled to the archipelago by four waves of migration (historylearning.com, 2019). Historylearning.com (2019) describes that on the third wave of migration theory of Beyer, " 6,000 years ago - a group of Indonesians capable of travelling across the sea and wielding tools became the first immigrants to reach the Philippines using the ocean". These theories show the similarities between the Philippines and Indonesian such as culture, physical attributes and the linguistic similarities. Thus, these theories lay down the connection of Indonesians and Filipinos.

\section{Filipino and Indonesian as Austronesian Languages}

The Austronesian language family comprises approximately 1,200 languages or $20 \%$ of the world's languages, spoken in a larger area from Madagascar to New Zealand, crossing several South East Asia countries such as Indonesia, Malaysia, and the Philippines (Blust, 2011; Klamer, 2019) by about 180-250 million speakers (Pereltsvaig, 2012). Due to the language family's number of languages and wideness of domain, Austronesian is among the largest language families (Lynch, 1998).

There are two major branches of the Austronesian language family. The first one is the Formosa branch that is composed of 20 languages that are native to Taiwan. The other one is the Malayo-Polynesian branch and it can be further divided into three subgroupings: Western Malayo-Polynesian, Central Malayo-Polynesian, and Eastern Malayo-Polynesian. Under the Western Malayo-Polynesian are Tagalog and Indonesian (Pereltsvaig, 2012). The standardized form of Tagalog is Filipino and it is the national language of the Philippines (Malabonga, 2009). Meanwhile, Indonesian's national language is Indonesian or the Indonesian language or bahasa Indonesia. In this study, these two will be juxtaposed and compared through linguistics, particulartly their phonological aspects.

\section{Linguistic Similarities of Filipino and Indonesian}

Since Filipino and Indonesian belong in the same language family, it is not surprising that the two of them display the same grammatical features and possess a lot of cognates. These features can be attributed to the "Austronesian prototype" (Pereltsvaig, 2012).

One of the properties of the Austronesian prototype that is present in both Filipino and Indonesian is the differentiation of the inclusive and exclusive first pronouns (Pereltsvaig, 2012). It does not exist in English because when you use 'we,' it does not indicate whether the hearer of the statement is included or not. However, in the Austronesian languages such as Tagalog and Indonesian, the speaker of the statement must stipulate whether or not the hearer is included in the 'we'. For instance, a Tagalog speaker must say 'tayo' if he/she includes the hearer and ' $k a m i$ ' if he/she excludes the hearer (Pereltsvaig, 2012).

Pereltsvaig (2012) argued that the Austronesian prototype also includes Austronesian 
languages' use of infixation -inserting an affix into the stem- and reduplication. The use of these helps in marking grammatical categories such as tense and number. For example, the infix -um in Tagalog which marks the Actor Topic, like the active voice found in the English language, is put in the word sulat ('write'). The infix is inserted in the stem after the first consonant making the word become sumusulat ('writing').

On the other hand, reduplication is the process of repeating of a word stem or a part of it (Urbanczyk, 2020). In Tagalog, partial reduplication happens to mark the verb in future tense. The first syllable of the word is the one being repeated like in sulat (write) which becomes susulat (will write). However, in Indonesian, full reduplication takes place in order to mark number. For instance, anak (child) becomes anak-anak (children) (Pereltsvaig, 2012).

\section{Vowels in Filipino and Indonesian}

The phonology of Filipino reflects the impact of colonization of Spain and America (Schachter \& Reid, 2009, p. 34). Because of the incorporation of numerous loanwords of English and Spanish, the phonemic inventory of Filipino expanded. This is evident on the development of the language's three-vowel system to a five-vowel system. Originally, [i] and [e] were considered as allophones of one phoneme and this was also the case of [u] and [o] (Schachter \& Reid, 2009). All these monophthong vowels can occur in any word position (Lim, 2014). Filipino's vowel phonemes are shown in the Table 1.

Wijana (2003) stated that Indonesian has a six-vowel system. This vowel system was also influenced by language contact. In fact Tadmor (2009, p. 796) reported that, "the phonemicisation of the mid vowels $(/ \mathrm{e} /, / \mathrm{\partial} /, / \mathrm{o} /)$ is the product of a combination of internal and external factors". The vowels /a/ and /a/ do not have allophones, therefore, they can occur in any word position. Meanwhile, the other vowels have allophones: /i/ can be realized as [i] and [i], the $/ \mathrm{u} /$ can be realized as $[\mathrm{u}]$ and $[\mathrm{v}]$, /e/ can be realized as $[\mathrm{e}]$ and $[\varepsilon]$, and /o/ can be realized as [o] and [0] (Wijana, 2003). The vowel phonemes of Indonesian are shown in Table 2.

Table 1. Vowel Phonemes of Filipino

\begin{tabular}{cccc}
\hline & Front & Central & Back \\
\hline High & $\mathrm{i}$ & & $\mathrm{u}$ \\
\hline Mid & $\mathrm{e}$ & & $\mathrm{o}$ \\
\hline Low & & $\mathrm{a}$ & \\
\hline
\end{tabular}

Source: Schachter \& Reid (2009, p. 834)

Table 2. Vowel Phonemes of Indonesian

\begin{tabular}{cccc}
\hline & Front & Central & Back \\
\hline High & i & & $\mathrm{u}$ \\
\hline Mid & $\mathrm{e}$ & $\partial$ & $\mathrm{o}$ \\
\hline Low & \multicolumn{3}{c}{$\mathrm{a}$} \\
\hline \multicolumn{3}{c}{ Source: } & Tadmor (2009, p. 795).
\end{tabular}

\section{METHOD}

This study utilizes qualitative method to compare the Filipino and Indonesian Language. Qualitative research focuses on qualitative data containing words, which can be collected through observation, interviews, or documents (Miles \& Huberman, 1994, 
p.9).

The source of the data to this study is the second edition of A Comprehensive Indonesian-English Dictionary by (Stevens, A. \& Schmidgall-Tellings, 2010) and Kamus Besar Bahasa Indonesia (Indonesian Official Dictionary) (Badan Pengembangan dan Pembinaan Bahasa, 2020a). The following are the criteria in choosing the words that will be used for the analysis: (1) the Indonesian word must differ in only one or two phonological element from the Filipino word; and (2) the Indonesian word must have a corresponding definition with the Filipino word that it is similar to. Those that did not manifest change in vowel and those that are exactly similar with Filipino words were not included in the data. Both the groups of Indonesiean and Filipino words were transcribed using the International Phonetic Alphabet (IPA). The purpose of this is to examine the difference of vowel in the two languages and to see if there are patterns in the changes of these vowels.

\section{FINDINGS AND DISCUSSION}

\section{Similarities and Differences in the Monophthongs of Filipino and Indonesian}

Based on the previous studies, Filipino has five monophthongs $(/ \mathrm{a} /, / \mathrm{e} / \mathrm{l} / \mathrm{i} /, / \mathrm{o} /$, and $/ \mathrm{u} /)$ whereas Indonesian has six $(/ \mathrm{a} /, / \mathrm{e} /, / \mathrm{\partial} /, / \mathrm{i} /, / \mathrm{o} /$, and $/ \mathrm{u} /)$. Both the languages have the monophthongs $(/ \mathrm{a} /, / \mathrm{e} / \mathrm{l} / \mathrm{i} /, / \mathrm{o} /$, and $/ \mathrm{u} /)$. However, unlike Indonesian, Filipino does not have the mid central unrounded vowel $/ \mathrm{\partial} /$.

\section{Changes in the Monophthongs from Filipino to Indonesian Low front unrounded vowel /a/ in Filipino}

Based on the data collected, there are 14 similar Filipino and Indonesian words that show change from a low front unrounded vowel /a/ in Filipino to different vowel phonemes in Indonesian as shown in Table 3. Out of 14 pairs of words, 12 of them change from a low front unrounded vowel /a/ in Filipino to a mid central unrounded vowel / $/$ / in Indonesian $(/ \mathrm{a} / \square / \mathrm{\partial} /)$. This change appears in initial and medial positions. From 10 out of 12 words, /a/ $\square / \mathrm{a} /$ occurs in medial position while in the two words, it occurs in initial position. Also, there is one word that shows change from a low front unrounded vowel /a/ in Filipino to a mid front unrounded /e/ in Indonesian (/a/ $\square / \mathrm{e} /)$. This change occurs in a medial position of a word. Lastly, a change from low front unrounded /a/ in Filipino to high back unrounded /u/ in Indonesian $(/ \mathrm{a} / \square / \mathrm{u} /)$ occurs in one word. The change appears from the initial position in Filipino to the medial position in Indonesian.

Table 3. Low front unrounded vowel /a/ in Filipino

\begin{tabular}{|c|c|c|c|c|c|}
\hline \multirow[t]{2}{*}{ No } & Filipino words & IPA & $\begin{array}{l}\text { Indonesian } \\
\text { words }\end{array}$ & IPA & $\begin{array}{c}\text { Definition } \\
\text { worried }\end{array}$ \\
\hline & \multicolumn{5}{|c|}{ Low front unrounded vowel /a/ to mid central unrounded vowel/o/ } \\
\hline 1 & baliko & /balikgo/ & beliku & /bəliku/ & bent \\
\hline 2 & apat & /apat/ & empat & /əmpat/ & four \\
\hline 3 & bandera & /bandera/ & bendera & /bəndəra/ & flag \\
\hline 4 & bangis & /benis/ & bengis & /benis/ & cruel \\
\hline 5 & sakal & /sekal/ & cekal & $/ \mathrm{t} \int \mathrm{\jmath kal} /$ & $\begin{array}{c}\text { to seize } \\
\text { with hand, } \\
\text { to grab }\end{array}$ \\
\hline 6 & anim & /anim/ & enam & /onam/ & six \\
\hline
\end{tabular}




\begin{tabular}{|c|c|c|c|c|c|}
\hline 7 & balisa & /balisp/ & gelisah & /gelisp/ & \\
\hline 8 & dangkal & /daykel/ & jengkal & /dzəykal/ & $\begin{array}{l}\text { a span (of } \\
\text { hand) }\end{array}$ \\
\hline 9 & sarap & /serap/ & sedap & /sədap/ & delicious \\
\hline 10 & kalis & /kalis/ & keris & /kəris/ & $\begin{array}{c}\text { a } \\
\text { ceremonial } \\
\text { dagger }\end{array}$ \\
\hline 11 & katok & /katok/ & ketok & /ketok/ & a knock \\
\hline 12 & kakulangan & /kakulayan/ & kekurangan & /kəkoranan/ & $\begin{array}{c}\text { insufficienc } \\
y\end{array}$ \\
\hline \multicolumn{6}{|c|}{ Low front unrounded vowel /a/ to mid front unrounded vowel /e/ } \\
\hline 13 & sandok & /sandok/ & séndok & /sendok/ & spoon, ladle \\
\hline \multicolumn{6}{|c|}{ Low front unrounded vowel /a/ to high back rounded vowel /u/ } \\
\hline 14 & angat & /ayat/ & jungat & /dzunat/ & $\begin{array}{l}\text { to tilt } \\
\text { upward at } \\
\text { one end }\end{array}$ \\
\hline
\end{tabular}

\section{Mid front unrounded vowel /e/ in Filipino}

There are two similar Filipino and Indonesian words that showed change from a mid front unrounded vowel /e/ in Filipino to either high front unrounded vowel /i/ or high back rounded vowel /u/ in Indonesian as shown in Table 4.

Table 4. Mid front unrounded vowel /e/ in Filipino

\begin{tabular}{|c|c|c|c|c|}
\hline Filipino words & IPA & $\begin{array}{c}\text { Indonesian } \\
\text { words }\end{array}$ & IPA & Definition \\
\hline \multicolumn{5}{|c|}{ Mid front unrounded vowel/e/ to high front unrounded vowel / } \\
\hline aktres & /aktres/ & aktris & /aktris/ & actress \\
\hline \multicolumn{5}{|c|}{ Mid front unrounded vowel /e/ to high back rounded vowel /u/ } \\
\hline semplang & /semplay/ & jomplang & /dzomplay/ & $\begin{array}{l}\text { to turn upside } \\
\text { down; } \\
\text { unbalanced, } \\
\text { unequal. }\end{array}$ \\
\hline
\end{tabular}

One word has a change from phoneme /e/ in Filipino to phoneme /i/ in Indonesian (/e/ $\square / \mathrm{i} /$ ) and the other has a change from from phoneme /e/ in Filipino to phoneme $/ \mathrm{u} / \mathrm{in}$ Indonesian $(/ \mathrm{e} / \square / \mathrm{u} /$ ). Both of these changes appeared in medial position.

\section{High front unrounded vowel /i/ in Filipino}

There are six similar Filipino and Indonesian words that exhibited change from a high front unrounded vowel / $\mathrm{i} /$ in Filipino to mid central unrounded /a/, low front unrounded vowel /a/, and high back rounded vowel /u/ in Indonesian as shown in Table

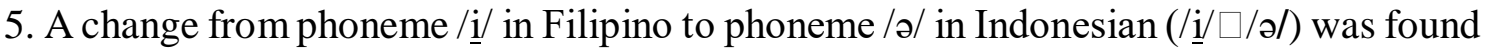
in medial position of four pair of words. Also, there is one words that showed change from phoneme / $\underline{i} /$ in Filipino to phoneme /a/ in Indonesian (/// $\square / \mathrm{a} /$ ) and it appeared in medial positions. Lastly, only one word was found to have a change from phoneme / $\mathrm{i} /$ in Filipino to phoneme /u/ in Indonesian $(/ \mathrm{i} / \square / \mathrm{u} /)$ that occurred in initial position. 
Table 5. High front unrounded vowel /i/ in Filipino

\begin{tabular}{|c|c|c|c|c|c|}
\hline No & Filipino words & IPA & $\begin{array}{c}\text { Indonesian } \\
\text { words }\end{array}$ & IPA & Definition \\
\hline & \multicolumn{5}{|c|}{ High front unrounded vowel /i/ to mid central unrounded vowel /a/ } \\
\hline 1 & bitak-bitak & /bitak-bitak/ & betak-betak & /bətak-bətak/ & $\begin{array}{c}\text { tattered, } \\
\text { dilapidated }\end{array}$ \\
\hline 2 & simbahan & /simbahan/ & sembahan & /səmbahan/ & $\begin{array}{c}\text { church, that is } \\
\text { worshipped, } \\
\text { God, idol }\end{array}$ \\
\hline 3 & sigok & /sigok/ & ceguk & /t fəguk/ & a swallow \\
\hline 4 & simula & /sımola/ & semula & /səmula/ & $\begin{array}{l}\text { beginning, } \\
\text { from the } \\
\text { beginning, in } \\
\text { the beginning }\end{array}$ \\
\hline \multicolumn{6}{|c|}{ High front unrounded vowel /i / to low front unrounded vowel /a/ } \\
\hline 5 & anim & /anim/ & enam & /onam/ & six \\
\hline \multicolumn{6}{|c|}{ High front unrounded vowel /i/ to high back rounded vowel /u/ } \\
\hline 6 & iba & /iba/ & ubah & /ubah/ & $\begin{array}{l}\text { different, to } \\
\text { change. }\end{array}$ \\
\hline
\end{tabular}

\section{Mid back rounded vowel /o/ in Filipino}

Table 6 shows sample words which have a change from a mid back rounded vowel /o/ in Filipino to high back rounded vowel /u/, low front unrounded vowel /a/, and mid central unrounded vowel /ə/ in Indonesian.

Table 6. Mid back rounded vowel /o/ in Filipino

\begin{tabular}{|c|c|c|c|c|c|}
\hline No & Filipino words & IPA & $\begin{array}{c}\text { Indonesian } \\
\text { words }\end{array}$ & IPA & Definition \\
\hline & \multicolumn{5}{|c|}{ Mid back rounded vowel /o/ to high back rounded vowel /u/ } \\
\hline 1 & ako & /ako/ & aku & /aku/ & me \\
\hline 2 & alon & /alon/ & alun & /alun/ & wave \\
\hline 3 & aparato & /aparato/ & aparatus & /aparatus/ & apparatus \\
\hline 4 & amok & /emok/ & amuk & lamok/ & amok \\
\hline 5 & ano & /pno/ & anu & /anw/ & $\begin{array}{l}\text { a word used } \\
\text { to represent } \\
\text { a pause in } \\
\text { order to } \\
\text { think for a } \\
\text { moment }\end{array}$ \\
\hline 6 & balot & /balot/ & balut & /balot/ & to wrap \\
\hline 7 & bangko & /benko/ & bangku & /bayku/ & bench \\
\hline 8 & baliko & /beliko/ & beliku & /beliku/ & bent \\
\hline 9 & buhol & /buhol/ & buhul & /buhol/ & knot \\
\hline 10 & buntot & /buntot/ & buntut & /buntot/ & tail \\
\hline 11 & sigok & /sigok/ & ceguk & /tfəguk/ & a swallow \\
\hline 12 & gulong & /guloy/ & gulung & /gulor/ & roll \\
\hline 13 & guro & /guro/ & guru & /guru/ & teacher \\
\hline
\end{tabular}




\begin{tabular}{|c|c|c|c|c|c|}
\hline 14 & hukom & /hukom/ & hukum & /hukum/ & law \\
\hline 15 & inspektor & /Inspektor/ & inspéktur & /Inspektor/ & inspector \\
\hline 16 & kangkong & /kaykon/ & kangkung & /kaykuy/ & $\begin{array}{l}\text { swamp } \\
\text { cabbage }\end{array}$ \\
\hline 17 & antok & /antok/ & kantuk & /kantuk/ & sleepines \\
\hline 18 & kulambo & /kulambo/ & kelambu & /kəlambu/ & $\begin{array}{c}\text { mosquito net } \\
\text { (over bed) }\end{array}$ \\
\hline 19 & kusot & /kusot/ & kusut & /kusot/ & $\begin{array}{l}\text { tousled (of } \\
\text { hair), tangled } \\
\text { (of thread) }\end{array}$ \\
\hline 20 & kuto & /kuto/ & kutu & /kutu/ & louse \\
\hline 21 & laot & /laot/ & laut & /laut/ & sea \\
\hline 22 & liko & /liks/ & liku & /liku/ & curve \\
\hline 23 & lumot & /lumst/ & lumut & /lumot/ & moss \\
\hline 24 & mangkok & /maykok/ & mangkuk & /maykuk/ & bowl \\
\hline 25 & linggo & /lingo/ & minggu & /mingu/ & $\begin{array}{c}\text { Sunday } \\
\text { (day), week }\end{array}$ \\
\hline 26 & inom & /Inom/ & minum & /minum/ & $\begin{array}{c}\text { to have a } \\
\text { drink }\end{array}$ \\
\hline 27 & payong & /pajoy/ & payung & /pajuy/ & umbrella \\
\hline 28 & pinto & /pInta/ & pintu & $/$ pintu/ & door \\
\hline 29 & libo & /libo/ & ribu & /ribu/ & thousand \\
\hline 30 & sangkot & /seykot/ & sangkut & /saykut/ & to hang \\
\hline 31 & sapot & /sapot/ & saput & /saput/ & thin film \\
\hline 32 & istasyon & /EstaJon/ & stasiun & /stasijun/ & station \\
\hline 33 & suso & /suso/ & susu & /susu/ & milk \\
\hline 34 & taho & /teho/ & tahu & /tahu/ & tofu \\
\hline 35 & taon & /teon/ & tahun & /tahon/ & year \\
\hline 36 & takot & /tekot/ & takut & /takut/ & to be afraid \\
\hline 37 & trilyon & /triljon/ & triliun & /triljun/ & trillion \\
\hline 38 & tumpok & /tumpok/ & tumpuk & /tumpok/ & pile \\
\hline 39 & umpok & /ompok/ & umpuk & /umpok/ & heap, pile \\
\hline 40 & urong & /uroy/ & urung & /uruy/ & $\begin{array}{c}\text { to be } \\
\text { canceled }\end{array}$ \\
\hline \multicolumn{6}{|c|}{ Mid back rounded vowel /o/ to low front unrounded vowel /a/ } \\
\hline 41 & dinamiko & /dinamiko/ & dinamika & /dinamika/ & dynamic. \\
\hline \multicolumn{6}{|c|}{ Mid back rounded vowel /o/ to mid central unrounded vowel /ə/ } \\
\hline 42 & tipo & /tipo/ & tipe & /tipa/ & type. \\
\hline
\end{tabular}

Out 42 words that exhibit this change, 40 of it specifically showed change from phoneme $/ \mathrm{o} /$ in Filipino to $/ \mathrm{u} /$ in Indonesian $(/ \mathrm{o} / \square / \mathrm{u} /)$. Most of it appears in medial position, with 27 pairs of words, and some appear in final position, with 13 pairs of words. Also, there is one word with a change from phoneme /o/ in Filipino to phoneme /a/ in Indonesian $(/ \mathrm{o} / \square / \mathrm{a} /)$ and the change appeared in its final position. Lastly, a change from phoneme $/ \mathrm{o} /$ in Filipino to phoneme $/ \mathrm{\partial} /$ in Indonesian $(/ \mathrm{a} / \square / \mathrm{u} /)$ occurred in the final position of a word. 


\section{High back rounded vowel /u/ in Filipino}

Table 7 shows some of the words that have a change from a high back rounded vowel /u/ in Filipino to either mid back rounded vowel/o/ or mid central unrounded vowel $/ \partial /$ in Indonesian. A total of five (5) pairs of similar words have been found to have such change in vowel phonemes. Four of these have a change from phoneme $/ \mathrm{u} /$ in Filipino to $/ \mathrm{o} /$ in Indonesian $(/ \mathrm{u} / \square / \mathrm{o} /)$, in their medial positions. The other word has a change from phoneme $/ \mathrm{u} /$ to phoneme / / / in Indonesian $(/ \mathrm{u} / \square / \mathrm{\partial} /)$ that occurs in the initial position.

Table 7. High back rounded vowel/u/ in Filipino

\begin{tabular}{|c|c|c|c|}
\hline No & $\begin{array}{c}\text { Indonesian } \\
\text { words }\end{array}$ & IPA & Definition \\
\hline \multicolumn{4}{|c|}{ High back rounded vowel /u/ to mid back rounded vowel /o/ } \\
\hline 1 & sontok & /sontok/ & to beat, strike, pound \\
\hline 2 & sosi & /sosi/ & key (to a lock) \\
\hline 3 & tolak & /tolak/ & push away \\
\hline 4 & tolong & /toloy/ & Help \\
\hline \multicolumn{4}{|c|}{ High back rounded vowel /u/ to mid central unrounded vowel /ə/ } \\
\hline 5 & kelambu & /kəlambu/ & mosquito net (over bed) \\
\hline
\end{tabular}

The researchers have found out that the changes occur mostly in medial position from vowel phonemes of Filipino to Indonesian. It is evident that the change from mid back rounded vowel /o/ in Filipino to high back rounded vowel /u/ in Indonesian vowel sound $(/ \mathrm{J} / \square / \mathrm{u} /)$ are more frequent and it occurs mostly in medial position. There are also constant changes from low front unrounded vowel/a/ in Filipino to mid central unrounded vowel /ə/ in Indonesian (/a/ $\square / \curvearrowright /)$ that occur mostly in medial position.

\section{CONCLUSION}

It is evident based on the findings from the selected corpora that were analyzed that most of the changes in monophthongs between the two languages appear in medial position. Moreover, most changes are from the mid back rounded vowel /o/ in Filipino language to high back rounded vowel /u/ in the Indonesian language. Additionally, the changes in the unrounded vowels in Filipino language usually appear in the initial and medial position whereas in the rounded vowels in Filipino, changes only appear in either the medial or final position. The research findings support the relationship between Filipino and Indonesian language as part of the same language family: Austronesian. Future research on the same topic may extend the scope of this present study and consider examining the changes in the consonant phonemes of the two languages. May this paper be a contribution on the analyses of Filipino and Indonesian's linguistic similarities and differences that may result to more exploration of both languages for future language programs and explorations.

\section{Acknowledgement}

The researchers would like to extend their sincerest thanks to everyone who supported and helped them, to make this study possible. They would like to express gratitude and appreciation towards their families who motivated them as they work on this study amidst COVID-19 pandemic. They would also like to thank the Polytechnic University of the Philippines, the Department of English, Foreign Languages and 
Linguistics, The DEFLL Extension and Student Corps. (ESC). They would also like to thank Prof. Rolando P. Quinones Jr, their organization's research adviser and Ms. Korinne Taloza, former ECS president, for imparting their knowledge and expertise in during and after the conduct of this linguistics study. Finally, this is dedicated to the BIPA Program officials and teachers for the usual support and energy in offering bahasa Indonesia courses in the university.

\section{REFERENCES}

Badan Pengembangan dan Pembinaan Bahasa. (2019). Bahasa dan Peta Bahasa di Indonesia. Retrieved July 27, 2020, from https://petabahasa.kemdikbud.go.id/

Badan Pengembangan dan Pembinaan Bahasa. (2020a). Kamus Besar Bahasa Indonesia. Retrieved July 23, 2020, from https://kbbi.kemdikbud.go.id/

Badan Pengembangan dan Pembinaan Bahasa. (2020b). Sekilas Tentang Sejarah Bahasa Indonesia. $\quad$ Retrieved July 27, 2020, from http://badanbahasa.kemdikbud.go.id/lamanbahasa/petunjuk_praktis/627/Sekilas Tentang Sejarah Bahasa Indonesia

Bellwood, P. (1984). A Hypothesis for Austronesian Origins. Asian Perspectives, XXVI(1), 107--117. Retrieved from https://core.ac.uk/download/pdf/5105193.pdf

Blust, R. (2011). Austronesian: A Sleeping Giant? Language and Linguistics Compass, 8, 538-550. https://doi.org/10.1111/j.1749-818x.2011.00297.x

Blust, R. (2018). Austronesian languages. Retrieved July 27, 2020, from https://www.britannica.com/topic/Austronesian-languages

Danielson, K. (2009). What is Southeast Asia? by. Retrieved from https://www.niu.edu/clas/cseas/_pdf/lesson-plans/k-12/southeast-asia.pdf

historylearning.com. (2019). Wave migration theory - Philippines. Retrieved July 24, 2020, from https://historylearning.com/history-of-the-philippines/prehistory/population-theories/wave-migration-theory/

Klamer, M. (2019). The dispersal of Austronesian languages in Island South East Asia : Current findings and debates, (July 2018), 1-26. https://doi.org/10.1111/lnc3.12325

Kusnandar, V. (2019). Jumlah Pulau di Indonesia Berkurang Menjadi 16 Ribu. Retrieved July 27, 2020, from https://databoks.katadata.co.id/datapublish/2019/06/12/jumlahpulau-di-indonesia-berkurang-menjadi-16-ribu

Lim, J. B. (2018). The Linguistic Similarities or Differences of Filipino Language and Bahasa Indonesia. University of Saint Anthony: Iriga City.

Lim, R. K. (2014). Nonlinear Phonological Analysis in Assessment of the University of phonological development in Tagalog. The University of British Columbia. Retrieved from https://open.library.ubc.ca/cIRcle/collections/ubctheses/24/items/1.0166067

Lynch, J. (1998). The History of the Austronesian Languages. In Pacific Languages: An Introduction (pp. 45--59). Honolulu: University of Hawai'i Press. Retrieved from https://www.jstor.org/stable/j.ctv893h2b.1?refreqid=excelsior\%3Abe09228b01fb5 1efa3ad50aa26973036\&seq=3\#metadata_info_tab_contents

Malabonga, V. (2009). Heritage Voices: Programs - Tagalog. Retrieved from http://www.cal.org/heritage/research/voices_tagalog.pdf

Miles, M. B., \& A. M. Huberman. (1994). Qualitative Data Analysis: An Expanded Source Book (1st ed.). London: SAGE Publications.

Mulyaningsih, D.H. (2014). Perbandingan Fonologi Bahasa Indonesia dan Bahasa 
Mandarin. BAHTERA: Jurnal Pendidikan Bahasa dan Sastra, 13(1), 1--10. https://doi.org/10.21009/BAHTERA.131.01

Pereltsvaig, A. (2012). Languages of the world: An introduction. Cambridge: Cambridge University.

Schachter, P., \& Reid, L. (2009). Tagalog. In B. Comrie (Ed.), The World's Major Languages (2nd ed) (pp. 833--855). Routledge.

Stevens, A. \& Schmidgall-Tellings, A. E. (2010). A Comprehensive Indonesian-English dictionary (2nd ed). Ohio: Ohio University Press.

Tadmor, U. (2009). Malay-Indonesian. In Bernard Comrie (Ed.), The world's major languages (2nd ed) (Second, pp. 791-818). London: Routledge.

Urbanczyk, S. (2020). Phonological and Morphological Aspects of Reduplication (pp. 128).

Oxford

University

Press

USA.

https://doi.org/10.1093/acrefore/9780199384655.013.80

Whitehead, D. (2013, February). Lobbying for English in Indonesia denies children mother-tongue education. Retrieved from https://www.theguardian.com/education/2013/feb/26/indonesia-mother-tongueenglish-debate

Wijana, I. D. P. (2003). Indonesian Vowels and Their Allophones. Humaniora, 15(1),

39-42. https://doi.org/https://doi.org/10.22146/jh.772

Wikipedia. (2020). Bahasa Indonesia. In Wikipedia. Retrieved from https://id.wikipedia.org/wiki/Bahasa_Indonesia 